\title{
PROBLEMATIKA FUNDRAISING ZAKAT: Studi Kasus Baznas di Sumatera Utara
}

\author{
Saparuddin Siregar \\ Pascasarjana UIN Sumatera Utara \\ J1. IAIN No. 1 Medan, Sumatera Utara, 20232 \\ e-mail: saparuddinss@yahoo.com
}

\begin{abstract}
Abstrak: Penghimpunan zakat di Indonesia telah memiliki payung hukum yang jelas. Akan tetapi, data penghimpunan (fundraising) zakat dan infak Badan Amil Zakat Nasional di Sumatera Utara periode 2015 menunjukkan perolehan zakat yang masih rendah yaitu hanya Rp. 14,55 milyar, dan infak sedekah Rp. 4,82 milyar. Penelitian ini bertujuan untuk menganalisis permasalahan yang dihadapi amil dalam penghimpunan zakat untuk menemukan rekomendasi solusi pemecahannya. Penelitian ini adalah penelitian deskriptif dengan mengambil sampel secara purposive beberapa cabang Badan Amil Zakat Nasional se-Sumatera Utara yang memiliki penghimpunan zakat terbesar. Data diperoleh dengan menggunakan kuesioner dan teknik wawancara. Metode analisis yang digunakan adalah dengan melakukan kristalisasi terhadap beberapa permasalahan pokok, sehingga didapati permasalahan yang paling mendasar. Hasil penelitian menunjukkan bahwa undang-undang dan peraturan zakat belum terlaksana secara efektif, pemerintah kurang memberi perhatian terhadap pengelolaan zakat, dan tidak dimilikinya sumber daya manusia profesional.
\end{abstract}

\begin{abstract}
The Problems of Zakat Fundraising: A Case Study of BAZNAS in North Sumatra. Alms' (zakat) fundraising in Indonesia has had comprehensive regulations. However, the collection amount of Alms and charity expenditure (infaq) by BAZNAS in North Sumatera in 2015 still low, it is only Rp 14.55 billion of Alms and Rp 4.82 billion of charity expenditure. This study aimed to analyze the problems faced by the alms collector (Amil) and to find the solutions. This study was descriptive research that took a purposive sample in some of BAZNAS's Branches in North Sumatera which have big amount of alms collection. The data were obtained using a questionnaire and interview techniques. The analytical method used to perform crystallization of some main issues, so that the most fundamental problem was found. The results showed that the laws and regulations of alms is not implemented effectively, the governments less on given attention to the management of alms and have not professionals human resources.
\end{abstract}

Kata Kunci: zakat, fundraising, Badan Amil Zakat Nasional, Lembaga Amil Zakat 


\section{Pendahuluan}

Pengelolaan zakat di Indonesia diatur melalui Undang-undang (UU) Nomor 23 tahun 2011 tentang pengelolaan zakat. UU yang disahkan tanggal 25 November 2011 ini menggantikan UU sebelumnya dengan Nomor 38 tahun 1999 tentang pengelolaan zakat. Untuk pelaksanaan UU Nomor 23 tahun 2011 ini telah terbit pula peraturan pemerintah (PP) Nomor 14 tahun 2014 tentang pelaksanaan UU Nomor 23 tentang pengelolaan zakat. Lebih lanjut terdapat pula Instruksi Presiden, yaitu Inpres Nomor 3 tahun 2014 tentang optimalisasi pengumpulan zakat di kementerian/lembaga, sekretariat jenderal lembaga negara, sekretariat jenderal komisi negara, pemerintah daerah, badan usaha milik negara, dan badan usaha milik daerah melalui Baznas. Lebih lanjut telah terdapat peraturan Baznas Nomor 1 tahun 2014 tentang pedoman tata cara pengajuan pertimbangan pengangkatan/pemberhentian pimpinan Baznas provinsi dan Baznas kabupaten/kota.

Perangkat UU dan peraturan zakat di Indonesia sangat cukup dan berkekuatan hukum, apalagi didukung dengan Inpres Nomor 3 tahun 2014 tentang optimalisasi pengumpulan zakat, dimana melalui Inpres ini terbuka kerjasama Baznas dengan semua institusi pemerintahan untuk melakukan pemotongan zakat. Namun, keberadaan Inpres sejak April 2014, hingga kini telah berumur dua tahun, perolehan penghimpunan zakat, infak dan sedekah (zis), masih jauh daripada potensi yang ada. Sari mencatat, meskipun pengelolaan zakat melibatkan banyak pihak, namun perolehan zakat belum optimal disebabkan lemahnya manajemen zakat yang memerlukan penanganan segera. ${ }^{1}$ Tahun 2014, perolehan zakat melalui amil zakat mencapai Rp. 2,77 triliun. Pada 2015, target zakat terkumpul Rp. 4,22 triliun atau Rp. 5 triliun. ${ }^{2}$ Perolehan ini masih pada kisaran $2 \%$ dari potensi zakat tahun 2011. Hasil riset Baznas dan Fakultas Ekonomi Manajemen (FEM) IPB tahun 2011 menunjukkan bahwa potensi zakat nasional mencapai angka 3,4 persen dari total produk domestik bruto (PDB). Dengan persentase ini, potensi zakat di Indonesia setiap tahunnya tidak kurang dari Rp. 217 triliun. Sedangkan khusus mengenai potensi zakat dari giro wadi'ah dan deposito mudhârabah di perbankan syariah saja, penelitian tersebut menemukan bahwa potensi zakat keduanya mencapai masing-masing sebesar Rp. 155 miliar dan Rp. 739 miliar. $^{3}$

Negara-negara Islam di dunia senantiasa mengalami pertumbuhan dalam penghimpunan zakat, namun pencapaian itu masih kurang dari 1\%. ${ }^{4}$ Salleh dan Abd. Rahman

${ }^{1}$ Mutiara Dwi Sari, et al., "Review on Indonesian Zakah Management and Obstacles," dalam Social Sciences, Vol. 2, Nomor 2, 2013, h. 86-87.

${ }^{2}$ Syariful Alam, "Baznas Targetkan Perolehan Zakat 2015 Rp 4,22 Triliun," dalam http:/ /www.rri.co.id, 18 Januari 2015; Redaksi Forum Zakat, "Ini Bukti Potensi Zakat di Indonesia Besar," dalam http://forumzakat.org, 9 Desember 2014.

3"IB Peduli," dalam http://pusat.baznas.go.id, 9 Desember 2014.

${ }^{4}$ Arifin Md. Salleh dan Ramawan Abdul Rahman, "The Important Role of Zakat Organizations to Reinforce World Zakat Program," dalam Zakat For Poverty Alleviation (Jakarta: FOZ dan WZF, 2011), h. 10 
mengidentifikasi adanya empat persoalan yang dihadapi dunia Islam dalam menghimpun zakat. Pertama, institusi zakat tidak terkoordinasi dan tersinkronisasi dengan baik. Kedua, masih terdapat penghimpunan zakat melalui lembaga tidak resmi. Ketiga, pertentangan regulasi lainnya dengan zakat. Keempat, kredibilitas institusi zakat. ${ }^{5}$ Dikaitkan dengan kondisi Indonesia, Juwaini memperkirakan, apabila dilakukan perbaikan regulasi dan tata kelola zakat, zakat pada tahun 2016 akan tumbuh sebesar 30\%, atau mencapai Rp. 5,46 Triliun. Angka 5,4 Trilyun ini masih berada pada kisaran 2,5\% dari potensinya. ${ }^{6}$ Hal yang sama menurut Beik, angka penghimpunan zakat dapat dicapai apabila ada intervensi yang kuat dari pemerintah melalui kebijakan untuk mewajibkan penghimpunan zakat secara nasional. ${ }^{7}$

Apabila diamati penghimpunan zakat infak dan sedekah (zis) di Sumatera Utara selama tahun 2015, maka hanya diperoleh Rp. 19,38 milyar, jumlah ini meningkat dibanding tahun 2014 yang berjumlah Rp. 13,72 Milyar, (lampiran-1). Namun demikian, penghimpunan zakat oleh Baznas se-Sumatera Utara ini masih jauh daripada potensi Zis yang ada. Sekretaris Baznas Sumatera Utara memperkirakan potensi zakat dan infak keseluruhan yang ada di Sumatera Utara, bisa mencapai angka di atas 2 triliun lebih. ${ }^{8}$ Dari perhitungan jumlah penghimpunan ini, dana yang dihimpun Baznas se-Sumatera Utara ini masih 0,95\% dari potensi tersebut.

Rendahnya penghimpunan zakat dalam koridor UU dan peraturan zakat yang terbilang telah memadai di Indonesia ini menimbulkan pertanyaan yang memerlukan penelitian. Pertama, bagaimana efektivitas UU dan peraturan zakat yang ada? Kedua, Bagaimana permasalahan-permasalahan yang ada di lingkungan Baznas se-Sumatera Utara terkait efektivitas UU dan peraturan zakat itu. Ketiga, apa solusi yang dapat direkomendasikan atas permasalahan yang dihadapi Baznas se-Sumatera Utara. Uraian ini akan menganalisis segi-segi kekuatan UU dan peraturan zakat yang ada, kemudian memverifikasi pelaksanaannya oleh beberapa subjek penelitian Baznas di Sumatera Utara, sehingga didapati akar permasalahan dan solusi yang patut direkomendasikan.

\section{Pendekatan dalam Fundraising Zakat}

Terdapat dua pendekatan dalam melakukan penghimpunan zakat (fundraising). Pertama, pendekatan melalui kekuasaan dari penguasa (pemerintah). Kedua, pendekatan melalui kekuasaan dan kerelaan muzaki.

IIbid, h. 11-12.

6"Prospek Zakat Indonesia 2016," dalam http://www.dompetdhuafa.org, 3 Mei 2016.

"Irfan Syauqi Beik, "Outlook Zakat Nasional 2014, Tantangan UU No 23/2011," dalam http://www.republika.co.id, 9 Desember 2014.

${ }^{8}$ Anto, "Diperkirakan Zakat di Sumut Rp. 2 Triliun," dalam http://harian.analisadaily.com, 20 Februari 2016. 


\section{Fundraising Zakat dengan Pendekatan Kekuasaan}

Pendekatan fundraising zakat melalui kekuasaan adalah cara penghimpunan zakat dengan inisiatif penguasa yang mengandung unsur pemaksaan atau sekurang-kurangnya tekanan untuk membayar zakat dari pihak penguasa. Penghimpunan zakat dengan pendekatan kekuasaan telah dicontohkan Rasulullah SAW. dan para khalifah. Untuk tugas menghimpun zakat, Rasulullah SAW. menunjuk petugas zakat yang dinamakan mushaddiq)(مصدق) atau sấi (سـاع- سـاعي- سعاة) yang berperan melakukan penagihan zakat dan melakukan penghitungan zakat dengan teliti. Al-Qardhâwi mencatat beberapa nama yang pernah ditugaskan Rasul sebagai petugas zakat adalah Abû Mas'ûd, Abû Jahm ibn Khuzaifah, 'Uqbah ibn 'Âmir, al-Dahhâk ibn Qays, Qays ibn Sâ'ad, 'Ubâdah ibn Shâmit dan Wâhid ibn 'Uqbah yang bertugas memungut zakat Bani Musthâliq. ${ }^{9}$

Banyak sekali nama-nama yang ditunjuk Rasul sebagai petugas zakat, selain yang disebut di atas. Di antaranya 'Uyainah ibn Hisn yang diutus ke Bani Tamîm, Buraidah ibn Hâsib diutus ke Bani Aslâm dan Bani Ghifâr, 'Abbâd ibn Bisyr diutus ke Bani Sulaim dan Bani Muzâinah, Râfi‘ ibn Mâkis diutus ke Bani Juhainah, Amr ibn Âsh diutus ke Bani Fazârah, Dhahhâk ibn Sufyân al-Kilâbi diutus ke Bani Zibyân. Lebih lanjut al-Qardhâwi mengutip Imâm Kattâni dari Kitab Tarâtib al-Idâriah, menyebutkan bahwa Sekretaris Rasul dalam urusan zakat adalah Zubeir ibn Awwâm. Apabila Zubeir berhalangan yang menggantikan adalah Jahm bin Sâlth dan Khuzaifah ibn Yâman. ${ }^{10}$

Sepeninggal Rasulullah, khalifah Abû Bakar (11-13 H/632-634 M) dalam masa kepemimpinannya yang singkat 2 (dua) tahun, disibukkan dengan adanya pemurtadan di kalangan umat dan keengganan sebagian umat membayar zakat. Demikian pentingnya kepatuhan membayar zakat oleh umat Islam pada ketika itu, menyebabkan khalifah Abû Bakar memaklumkan perang kepada pembangkang zakat. Dengan demikian, tidak ada alasan bagi umat Islam untuk membangkang membayar zakat yang harus dipungut oleh petugas-petugas yang ditunjuk oleh pemerintahan Islam ketika itu.

Pada masa khalifah Abû Bakar terjadi peningkatan volume penghimpunan zakat, sehingga Abu Bakar merasa perlu memisahkan jabatan Amir al-Kharâj (pengumpul Pajak) dan Shâhib Bait al-Mâl (pejabat bendahara). ${ }^{11}$ Sejak masa Rasulullah sampai masa khalifah 'Umar bin Khaththâb,pelaksanaan penghimpun zakat adalah dengan pendekatan kekuasaan, dimana pemerintahan Islam mewajibkan umat Islam membayar zakat melalui petugaspetugas zakat yang ditunjuk oleh pemerintahan Islam. Wajar saja apabila negara Islam seperti Malaysia memberlakukan hukuman kepada warganya yang tidak taat membayar zakat. Sesuai UU syariah wilayah persekutuan 1974, yang tidak membayar zakat diganjar hukuman denda satu ribu ringgit atau dipenjara selama tidak melebihi enam bulan, atau kedua-duanya.

${ }^{9}$ Yûsuf al-Qardhâwî, Fikih al-Zakâh (Beirut: Mu'assasâh al-Risâlah, 1988), h. 749-750.

${ }^{10} \mathrm{Ibid}$, h. 751-752.

${ }^{11}$ Irfan Mahmud Ra'âna, Sistem Ekonomi Pemerintahan 'Umar Ibn al-Khatab (Jakarta: Pustaka Firdaus, 1997), h. 152-153. 


\section{Fundraising dengan Pendekatan Campuran}

Pada zaman khalifah 'Utsmân ibn 'Affân, harta umat Islam bertambah banyak, khalifah 'Utsmân melihat kemaslahatan untuk menyerahkan pemenuhan zakat itu pada pemiliknya, berdasarkan ijmak sahabat, sehingga pemilik harta itu seakan-akan menjadi wakil dari penguasa. Pada dasarnya penguasalah yang mengumpukan harta zakat baik harta lahir maupun harta batin, namun pada ketika sulit mengumpulkan harta batin karena bait al-mal juga telah penuh dengan timbunan harta, maka khalifah 'Ustmân memberi kebebasan kepada pemiliknya untuk mengeluarkan zakat harta batinnya sendiri. ${ }^{12}$ Namun terhadap harta lahir seperti hasil peternakan dan hasil pertanian tetap ditagih oleh petugas zakat yang ditunjuk pemerintahan Islam. Dengan demikian, pada masa khalifah 'Utsmân ibn 'Affân ini penghimpunan zakat lahir dilakukan oleh petugas zakat, sedangkan terhadap harta batin, pengumpulannya atas inisiatif muzaki. Khalifah 'Ustmân memberi kelonggaran menyetorkan sendiri harta batin atas inisiatif muzaki sangat dimungkinkan, karena kualitas keimanan dan keislaman umat pada ketika itu yang sangat tinggi, sehingga meskipun diberi kelonggaran seperti itu tidak akan mengurangi volume zakat yang akan terhimpun oleh pemerintahan Islam. Namun, dalam kondisi umat yang pada umumnya lemah keimanan dan keislaman seperti belakangan ini perlu digunakan pendekatan kekuasaan.

\section{Pengelolaan Zakat di Indonesia}

\section{Penghimpunan Zakat sejak Kerajaan Islam}

Usaha penghimpunan zakat di Indonesia menurut Zarkasyi telah tertata dengan baik sejak masuknya Islam di Indonesia, yaitu sejak masa kesultanan atau kerajaan Islam di Nusantara. Kesultanan Islam mengelola zakat dan mengatur pemanfaatannya untuk kepentingan umat Islam. Setelah berakhirnya kesultanan Islam pada tahun 1813 karena dihancurkan oleh kolonialisme, maka sejak saat itu zakat diperankan oleh masyarakat melalui masjid-masjid dan ulama di tingkat lokal. Steenbrink mengungkapkan, pada 1866 pemerintah mengeluarkan peraturan (bijblad 1892) yang melarang keras kepala desa sampai bupati turut campur dalam pengumpulan zakat. Peraturan tersebut mengakibatkan penduduk di beberapa tempat enggan mengeluarkan zakat atau tidak memberikannya kepada penghulu dan na’ib, melainkan kepada ahli agama yang dihormati, yaitu kiai atau guru mengaji. ${ }^{13}$ Inilah awal pelemahan penghimpunan zakat oleh unsur penguasa.

\section{Inisiatif dari Kalangan Pemerintah}

Upaya penghimpunan zakat yang terorganisir mulai dipelopori oleh organisasi

\footnotetext{
${ }^{12} I b i d$, h. 773.

${ }^{13}$ M. Fuad Nasar, "Zakat dalam Riwayat Pemerintahan Indonesia," dalam http://pusat.baznas.go.id, 15 Januari 2015.
} 
Muhammadiyah (1912) di bawah kepemimpinan K.H. Ahmad Dahlan di Yogyakarta, namun penghimpunan ini masih terbatas di kalangan anggotanya. Inisiatif dari kalangan pemerintah diawali pada masa Menteri Agama K.H. Saifuddin Zuhri. Kementerian Agama tahun 1964 menyusun rancangan UU tentang pelaksanaan zakat dan rancangan peraturan pemerintah pengganti UU tentang Pelaksanaan Pengumpulan dan Pembagian Zakat serta Pembentukan Baitul Mal. Akan tetapi rancangan produk legislasi tersebut batal diajukan ke DPR. Pada tahun 1967, Kementerian Agama kembali menyiapkan rancangan UU zakat, namun tidak mendapat dukungan dari Menteri Keuangan sebagai kementerian terkait, sehingga pembahasannya dihentikan. ${ }^{14}$ Setahun kemudian terbit Peraturan Menteri Agama Nomor 4 tahun 1968 tentang Pembentukan Badan Amil Zakat dan Peraturan Menteri Agama Nomor 5 tahun 1968 tentang pembentukan Baitul Mal di tingkat pusat, provinsi dan kabupaten/kotamadya. Namun, dalam waktu berdekatan Presiden Soeharto dalam acara peringatan Isrâ' dan Mirâjj Nabi Muhammad SAW. di istana negara 26Oktober 1968 mengumumkan bahwa sebagai pribadi beliau bersedia untuk mengurus pengumpulan zakat secara besarbesaran. Pernyataan Presiden Soeharto tahun 1968 menganulir pelaksanaan peraturan Menteri Agama terkait dengan zakat dan baitul mal. Tidak lama kemudian Instruksi Menteri Agama Nomor 1 tahun 1969 menyatakan pelaksanaan Peraturan Menteri Agama Nomor 4 dan Nomor 5 tahun 1968 ditunda sampai batas waktu yang tidak ditentukan. ${ }^{15}$

Pada tahun 1969, pemerintah mengeluarkan Keputusan Presiden Nomor 44 tahun 1969 tentang Pembentukan Panitia Penggunaan Uang Zakat yang diketuai Menko Kesra Dr. KH. Idham Chalid. Perkembangan selanjutnya di lingkungan pegawai kementerian/ lembaga/BUMN dibentuk pengelola zakat di bawah koordinasi Badan Kerohanian Islam setempat. Di tingkat wilayah pelembagaan zakat dipelopori dengan terbentuknya Bazis DKI Jakarta dengan keputusan gubernur Ali Sadikin tanggal 5 Desember 1968 yang dilatarbelakangi rekomendasi pertemuan 11 orang alim ulama di ibukota yang dihadiri antara lain oleh Buya Hamka dan tanggapan atas pidato Presiden Soeharto 26 Oktober 1968. Keberadaan pengelola zakat semi-pemerintah secara nasional dikukuhkan dengan Surat Keputusan bersama (SKB) Menteri Dalam Negeri dan Menteri Agama Nomor 29 dan Nomor 47 tahun 1991 tentang Pembinaan Bazis. ${ }^{16}$ Pembentukan Badan Amil zakat (BAZ) oleh Pemda DKI Jakarta kemudian diikuti oleh provinsi-provinsi lain yang dipelopori oleh pejabat atau unsur pemerintah dengan dukungan para ulama. Dengan demikian, terbentuklah badan amil zakat yang bersifat semi pemerintah yang pada umumnya didasarkan surat keputusan gubernur. Populasi BAZ meningkat dan terbentuk di Aceh (1975), Sumatera Barat (1975), Sumatera Selatan, Lampung (1975), Jawa Barat (1974), Kalimantan selatan (1977), Kalimantan Timur (1972), Sulawesi Selatan, Sulawesi Utara (1985) dan Nusa Tenggara Barat. Badan amil ketika itu hadir dengan nama yang berbeda-beda, seperti BAZ, Bazis,

${ }^{14}$ Ibid.

${ }^{15}$ Ibid.

${ }^{16}$ Ibid. 
Bazi, Bazid (ditambah derma) atau nama-nama lain seperti badan harta agama (Aceh), lembaga harta agama Islam (Sumatera Utara), dan yayasan sosial Islam (Sumatera Barat).

\section{Pengelolaan Zakat Diatur dengan Undang-Undang}

Pelaksanaan zakat di Indonesia diatur dalam UU pertamakali adalah dengan terbitnya UU Nomor 38 tahun 1999 tentang Pengelolaan Zakat. Pelaksanaan dari UU ini diatur oleh keputusan Menteri Agama Nomor 581 tahun 1999 dan dirinci lagi oleh keputusan Dirjen Bimas Islam Nomor D-291 tahun 2000 tentang pedoman teknis pengelolaan zakat. Selanjutnya, pada tahun 2003, Menteri Agama mengeluarkan keputusan Nomor 373 untuk menyempurnakan keputusan sebelumnya. Dasar pemikiran lahirnya UU ini adalah bahwa zakat merupakan sumber daya umat Islam yang sangat potensial untuk mewujudkan kesejahteraan masyarakat. Zakat juga sebagai pranata sosial yang merupakan bentuk kepedulian umat Islam yang berkemampuan terhadap sesamanya yang kurang mampu secara ekonomi.

Upaya pemerintah untuk memperkuat institusi zakat diwujudkan dengan terbitnya UU Nomor 23 tahun 2011 tentang pengelolaan zakat sebagai penyempurnaan UU Nomor 38 tahun 1999 dan peraturan-peraturan sebelumnya. Dalam UU Nomor 23 ini diatur, pemerintah berkewajiban memberikan perlindungan, pembinaan dan pelayanan kepada semua unsur yang terkait dengan zakat, baik muzaki, mustahiq maupun amil. Perlindungan yang dimaksud adalah memberikan jaminan kepastian hukum terhadap pelaksanaan zakat. Setiap unsur yang berkait dengan pelaksanaan zakat, baik penerimaan, pengelolaan dan pendistribusian zakat diatur dan dijamin oleh peraturan. Pelaksanaan dari UU ini, diatur oleh Peraturan Pemerintah Nomor 14 tahun 2014. Lebih lanjut, untuk mendorong kerjasama Baznas kepada seluruh institusi, Presiden menerbitkan Inpres Nomor 3 tahun 2014 tentang optimalisasi pengumpulan zakat pada lingkup kementerian/lembaga, sekretariat jenderal lembaga negara, sekretariat jenderal komisi negara, pemerintah daerah, badan usaha milik negara, dan badan usaha milik daerah.

Yulianti dan Suryandari mencatat bahwa pengelolaan zakat di Indonesia telah mengalami perkembangan sangat pesat jika dibandingkan tahun-tahun sebelumnya. Potensi zakat di Indonesia sangat besar namun belum terkelola secara optimum. Dalam proses menuju perbaikan prestasi, Undang-undang Nomor 23 tahun 2011 tentang Pengelolaan Zakat akan mendorong upaya pembentukan institusi zakat yang diharapkan dapat amanah, kuat dan dipercaya masyarakat. Jenis institusi zakat yang diakui dalam UU Zakat yaitu Baznas dan Laz serta Upz, menempatkan pemerintah berfungsi sebagai fasilitator, koordinator, motivator dan pengatur bagi pengurusan zakat yang dilakukan oleh Baznas, Laz dan Upz tersebut. Pemerintah mendorong agar institusi zakat menjadi institusi yang profesional, amanah, tulus, dan berdikari. ${ }^{17}$

\footnotetext{
${ }^{17}$ Rahmani Timorita Yulianti dan Ratnawati Yuni Suryandari, "Suatu Ulasan Kritis Tentang
} 


\section{Beberapa Ketentuan Undang-undang Nomor 23 Tahun 2011}

\section{Baznas dan Laz}

Lembaga yang berwenang melakukan pengelolaan zakat di Indonesia adalah Baznas (Badan Amil Zakat Nasional) dan Lembaga Amil Zakat atau disingkat Laz. Baznas dapat membentuk satuan organisasi yang dinamakan unit pengumpul zakat (Upz) yang tugasnya membantu pengumpulan zakat. Baznas berkedudukan di ibukota negara dibentuk oleh Pemerintah. Baznas merupakan lembaga pemerintah nonstruktural yang bersifat mandiri dan bertanggung jawab kepada presiden melalui menteri. Baznas merupakan lembaga yang berwenang melakukan tugas pengelolaan zakat secara nasional.

Laz adalah lembaga yang dibentuk atas inisiatif masyarakat untuk melaksanakan pengumpulan, pendistribusian, dan pendayagunaan zakat. Laz dapat menggunakan hak amil untuk membiayai kegiatan operasionalnya. Ketentuan bahwa Laz harus terdaftar sebagai organisasi kemasyarakatan Islam yang mengelola bidang pendidikan, dakwah dan sosial dapat dipahami sebagai suatu upaya melindungi agar pengelolaan zakat berada pada koridor kepentingan umat dan menghindari terjadinya pertentangan kepentingan (conflict of interest) yang mengarah kepada kepentingan pribadi, perusahaan, partai dan golongan. Demikian pula ketentuan memiliki pengawas syariat, bersedia diaudit syariat dan keuangan, ini menunjukkan upaya perlindungan agar dana zakat tidak disalah gunakan.

Sebagaimana lembaga yang resmi dan diperkenankan mengelola zakat adalah Baznas dan Laz, setiap orang dilarang dengan sengaja bertindak selaku amil zakat melakukan pengumpulan, pendistribusian, atau pendayagunaan zakat tanpa izin pejabat yang berwenang. Setiap orang dilarang melakukan tindakan memiliki, menjaminkan, menghibahkan, menjual, dan/atau mengalihkan zakat, infak, sedekah, dan/atau dana sosial keagamaan lainnya yang ada dalam pengelolaannya. Frasa, "setiap orang" dalam Pasal 38 dan Pasal 41 UU Nomor 23 tahun 2011 tentang Pengelolaan zakat "mengecualikan perkumpulan orang, perseorangan tokoh umat Islam (alim ulama), atau pengurus/takmir masjid/musala di suatu komunitas dan wilayah yang belum terjangkau oleh BAZ dan Laz, dan telah memberitahukan kegiatan pengelolaan zakat dimaksud kepada pejabat yang berwenang".

\section{Kepengurusan Baznas}

Baznas pusat berkedudukan di ibukota negara. Dalam rangka pelaksanaan pengelolaan zakat pada tingkat provinsi dan kabupaten/kota dibentuk Baznas provinsi dan Baznas kabupaten/kota. Baznas provinsi dibentuk oleh menteri atas usul gubernur setelah mendapat pertimbangan Baznas. Baznas kabupaten/kota dibentuk oleh menteri atau pejabat yang ditunjuk atas usul bupati/walikota setelah mendapat pertimbangan Baznas. Dalam hal

Peranan Kepimpinan dalam Membangun Profesionalisme Institusi Zakat," dalam Geografia: Malaysian Journal of Society and Space, 10 Issue 2, 2014, h. 143. 
gubernur atau bupati/walikota tidak mengusulkan pembentukan Baznas provinsi atau Baznas kabupaten/kota, menteri atau pejabat yang ditunjuk dapat membentuk Baznas provinsi atau baznas kabupaten/kota setelah mendapat pertimbangan Baznas.

Kepengurusan Baznas terdiri atas 11 (sebelas) orang anggota, masing-masing 8 (delapan) orang dari unsur masyarakat dan 3 (tiga) orang dari unsur pemerintah. Unsur masyarakat mewakili unsur ulama, tenaga profesional, dan tokoh masyarakat Islam sedangkan unsur pemerintah ditunjuk dari kementerian/instansi yang berkaitan dengan pengelolaan zakat, dalam hal ini Kementerian Agama. Baznas dipimpin oleh seorang ketua dan seorang wakil ketua, dengan masa kerja anggota Baznas dijabat selama 5 (lima) tahun dan dapat dipilih kembali untuk 1 (satu) kali masa jabatan.

Sesuai PP Nomor 14 tahun 2014 tentang Pengelolaan zakat, Baznas provinsi dibentuk oleh menteri atas usul gubernur setelah mendapat pertimbangan Baznas. Susunan organisasi Baznas provinsi dan Baznas kabupaten/kota terdiri atas unsur pimpinan dan pelaksana. Pimpinan terdiri atas ketua dan paling banyak 4 (empat) orang wakil ketua. Pimpinan berasal dari unsur masyarakat yang meliputi ulama, tenaga profesional, dan tokoh masyarakat Islam. Pelaksana berasal dari bukan pegawai negeri sipil. Namun jika diperlukan, maka pelaksana dapat berasal dari pegawai negeri sipil yang diperbantukan.

Untuk dapat diangkat sebagai anggota pengurus Baznas provinsi maupun Baznas kabupaten, paling sedikit harus memenuhi persyaratan: warga negara Indonesia; beragama Islam; bertakwa kepada Allah SWT; berahlak mulia; berusia paling sedikit 40 (empat puluh) tahun; sehat jasmani dan ruhani; tidak menjadi anggota partai politik; memiliki kompetensi di bidang pengelolaan zakat; dan tidak pernah di hukum karena melakukan tindak pidana kejahatan yang diancam dengan pidana penjara paling singkat 5 (lima) tahun.

Sesuai peraturan Baznas Nomor 1 tahun 2014 tentang pedoman tata cara pengajuan pertimbangan pengangkatan/pemberhentian pimpinan Baznas provinsi dan Baznas kabupaten/ kota, inisiatif untuk membentuk pengurus Baznas provinsi ada pada Gubernur dengan membentuk tim seleksi. Demikian pula untuk membentuk pengurus Baznas kabupaten/ kota dengan inisiatif bupati/walikota dengan membentuk tim seleksi. Tim seleksi memilih calon ketua Baznas provinsi atau Baznas kabupaten/kota sebanyak dua kali calon yang dibutuhkan. gubernur, bupati/walikota memilih lima orang calon pimpinan Baznas provinsi untuk disampaikan kepada Baznas Indonesia untuk mendapat pertimbangan.

\section{Baznas Dibiayai APBN/APBD dan Hak Amil}

Baznas pusat dibiayai dengan APBN (Anggaran Pendapatan dan Belanja Negara), (Anggaran Pendapatan dan Belanja Daerah) dan hak amil. Dalam melaksanakan tugasnya Baznas dapat bekerja sama dengan pihak terkait sesuai dengan ketentuan peraturan perundang-undangan. Baznas provinsi dan Baznas kabupaten/kota melaksanakan tugas dan fungsi Baznas di provinsi atau kabupaten/kota masing-masing. Untuk membiayai 
operasionalnya, Baznas provinsi dan Baznas kabupaten/kota dibiayai dengan APBD (Anggaran Pendapatan dan Belanja Daerah) dan hak amil. Baznas provinsi dan Baznas kabupaten/ kota dapat pula dibiayai dengan APBN.

\section{Inpres Nomor 3 Tahun 2014}

Instruksi Presiden Nomor 3 tahun 2014 tentang mengoptimalkan pengumpulan zakat adalah Inpres yang yang sangat kuat (powerfull) untuk dijadikan dasar menghimpun zakat. Inpres ini meliputi: Pertama, pengumpulan zakat di lingkup kementerian/lembaga, sekretariat jenderal lembaga negara, sekretariat jenderal komisi negara, pemerintah daerah, badan usaha milik negara, dan badan usaha milik daerah masing-masing, Kedua, khusus kepada: Menteri Dalam Negeri, diminta mendorong gubernur dan bupati/walikota untuk melakukan optimalisasi pengumpulan zakat di satuan kerja/organisasi perangkat daerah dan badan usaha milik daerah melalui badan amil zakat nasional provinsi/kabupaten/ kota, menteri badan usaha milik negara mendorong direksi/pimpinan badan usaha milik negara untuk melakukan optimalisasi pengumpulan zakat karyawan dan zakat badan usaha di lingkungan badan usaha milik negara melalui badan amil zakat nasional. Ketua badan amil zakat nasional untuk melakukan registrasi muzaki bagi pegawai/karyawan di kementerian/lembaga, sekretariat jenderal lembaga negara, sekretariat jenderal komisi negara, pemerintah daerah, badan usaha milik negara, dan badan usaha milik daerah membuat mekanisme teknis pengumpulan zakat di lingkungan kementerian/lembaga, sekretariat jenderal lembaga negara, sekretariat jenderal komisi negara, pemerintah daerah, badan usaha milik negara, dan badan usaha milik daerah. Melakukan pengumpulan zakat di lingkungan kementerian/lembaga, sekretariat jenderal lembaga negara, sekretariat jenderal komisi negara, pemerintah daerah, badan usaha milik negara, dan badan usaha milik daerah; dan menyampaikan laporan hasil pengelolaan zakat di kementerian/lembaga, sekretariat jenderal lembaga negara, sekretariat jenderal komisi negara, pemerintah daerah, badan usaha milik negara, dan badan usaha milik daerah terkait kepada pimpinan instansi dengan tembusan kepada Presiden melalui Menteri Agama.

Berdasarkan UU dan peraturan terkait pengelolaan zakat di atas, tampak telah terkandung maksud agar zakat di Indonesia dapat dikelola secara profesional dan optimal. Indikasi dimaksud terdapat pada pengaturan sebagai berikut: Institusi yang terdaftar atas nama "Baznas" dan "Laz", diharapkan akan menciptakan koordinasi secara nasional. Kepengurusan yang terdiri dari profesional, bukan anggota partai politik, memiliki kompetensi di bidang zakat, dan pendanaan dibiayai APBN/APBD dan dari dana amil. Kandungan maksud UU di atas sejalan dengan persyaratkan Amil zakat yang profesional oleh Yulianti dan Suryandari, yaitu bekerjafull time, dan mendapat gaji yang cukup, sehingga dapat mencurahkan segala potensinya untuk mengelola zakat dengan baik. ${ }^{18}$

\footnotetext{
${ }^{18}$ Ibid., h. 149.
} 


\section{Metode Penelitian}

Penelitian ini adalah penelitian kualitatif yang menganalisis permasalahan dalam penghimpunan dan ZIS oleh Baznas se-Sumatera Utara. Sampel penelitian dipilih secara purposive terhadap Baznas di provinsi/kabupaten/kota yang melakukan penghimpunan ZIS dalam jumlah yang besar. Sample dimaksud adalah Baznas Sumatera Utara. Baznas Kabupaten Langkat. Baznas Kota Sibolga. Baznas Kabupaten Asahan, Baznas Kota Binjai, Baznas Deli Serdang dan Baznas Kabupaten Tapanuli Tengah. Penelitian telah dilakukan selama bulan April tahun 2015, kemudian dilakukan update data kembali pada bulan Mei 2016.

Sumber data penelitian ini terdiri atas sumber primer dan sekunder. Sumber primer berasal dari jawaban informan, yaitu para narasumber pengurus maupun staf yang memiliki otoritas menjawab dari masing-masing Baznas. Adapun sumber sekunder adalah laporan penghimpunan ZIS yang diperoleh dari masing-masing Baznas ataupun yang diperoleh dari Baznas Sumatera Utara. Di samping itu berupa literatur kepustakaan, surat kabar, dan jurnal.

Metode pengumpulan data dilakukan dengan mengajukan pertanyaan tertutup maupun terbuka tentang permasalahan dan mendiskusikannya dengan informan untuk mendapatkan jawaban yang lebih mendasar. Metode analisa yang dilakukan adalah dengan melakukan komparasi antara ketentuan yang ada pada UU zakat dengan fakta empiris di Baznas masing-masing.

\section{Hasil dan Pembahasan}

\section{Hasil Penelitian}

Dari wawancara dengan masing-masing Baznas yang menjadi subjek penelitian diperoleh informasi sebagai berikut. Baznas Langkat adalah yang pertama di Sumatera Utara yang telah membentuk kepengurusan sesuai PP Nomor 14 tahun 2014. Pengurus telah ditetapkan oleh Bupati Langkat tanggal 2 Maret 2016. Pengurus adalah para profesional sebanyak 5 orang yang tidak berstatus PNS. Mulai tahun 2016 ini diharapkan bisa fokus mengurus Baznas Kabupaten Langkat.

Baznas langkat memiliki staf sebanyak 5 orang. Staf ini pada mulanya mendapat gaji yang berasal dari dana APBD, namun dalam 2 tahun terakhir tidak diperoleh dana operasional dari Bupati. Karena itu, untuk mendanai operasional menggunakan dana amil yang berasal dari infak sebesar 20\%. Pegawai memperoleh gaji Rp. 1.200.000,- perbulan. Tambahan penghasilan adalah dari kegiatan-kegiatan Baznas yang dilakukan. Baznas memperoleh penghimpunan zakat dari gaji PNS Kemenag, beberapa dinas lain masih 
menyalurkan berupa infak. Saat ini, DPRD sedang merancang Ranperda dalam rangka penghimpunan zakat. ${ }^{19}$

Baznas Deli Serdang sampai dengan awal Mei Baznas Deli Serdang belum membentuk kepengurusan baru sesuai PP Nomor 14. Saat ini sedang proses membentuk panitia seleksi dengan berkoordinasi dengan Pemkab Deli Serdang. Perolehan zakat telah teratur dari Kemenag, tetapi instansi-instansi lainnya belum melakukan pembayaran zakat. Staf hanya satu orang dengan pembiayaan honornya berasal dari dana infak. Honor yang diterima Rp. 1.200.000,- perbulan. Pemerintah Kabupaten Deliserdang tidak menyiapkan dana secara khusus untuk operasional, akan tetapi terdapat anggaran untuk kegiatan Baznas sebesar Rp. 25.000.000,- pertahun. Pengurus seluruhnya adalah pegawai Kemenag yang diberi tambahan tugas mengurus Baznas. ${ }^{20}$

Sampai dengan awal Mei, Baznas Binjai belum membentuk kepengurusan baru sesuai PP Nomor 14. Saat ini bermaksud akan membentuk panitia seleksi dengan berkoordinasi dengan Pemko Binjai. Perolehan zakat telah teratur dari Kemenag, tetapi instansi-instansi lainnya belum melakukan pembayaran zakat. Terdapat 2 orang staf dengan pembiayaan honornya berasal dari dana infak. Honor yang diterima Rp. 750.000/ per-orang perbulan. Pemko Binjai tidak menyiapkan dana untuk operasional. Seluruh pengurus adalah pegawai Kemenag. ${ }^{21}$

Baznas Tapanuli Tengah masih memiliki struktur organisasi yang lama dan belum menyesuaikan ke PP Nomor 14. Ada kekhawatiran jika menyesuaikan dengan PP Nomor 14 tanpa didukung honor, maka organisasi Baznas tidak tidak dapat berjalan dengan baik, karena pengurusnya pasti mengharapkan gaji, setidaknya dari hak Amil, padahal selama ini tidak diambil dari hak amil. Kepengurusan Baznas Tapanuli Tengah adalah rangkap jabatan dari pejabat pemerintah Kabupaten Tapanuli Tengah. Terdapat staf honor satu orang dengan gaji Rp. 500.000 per-bulan. Sebagian kantor disewakan dan memperoleh uang sewa Rp. 5.000.000,- pertahun. Uang sewa inilah yang digunakan untuk pembayar honor staf administrasi. Baznas Tapanuli Tengah tidak menghimpun zakat dari pegawai Kemenag. Tetapi memperoleh zakat infak sedekah dari dinas-dinas di Kabupaten Tapanuli Tengah. Zakat tidak ditetapkan potongan 2,5 persen dari gaji, tetapi sesuai kerelaan masingmasing. Infak ditetapkan Rp. 5.000,- untuk golongan I, Rp. 10.000,- untuk golongan dua dan Rp. 15.000,- untuk golongan III dan Rp. 20.000,- untuk golongan empat. Jumlah perolehan ini bersama zakat berjumlah Rp. 300.000.000,- pada tahun 2015. Baznas Tapanuli Tengah memperoleh anggaran dari pemerintah kabupaten untuk pembelian peralatan Rp. 40.000.000,pada tahun $2015 .^{22}$

\footnotetext{
${ }^{19}$ Wawancara dengan Idul Bashar, Staf Baznas Langkat, 4 Mei 2016.

${ }^{20}$ Wawancara dengan Iwan Rosadi, Sekretaris Baznas Deli Serdang, 4 Mei 2016.

${ }^{21}$ Wawancara dengan Rajo Amad, Sekretaris Baznas Binjai, 4 Mei 2016.

${ }^{22}$ Wawancara dengan Ramli, Bendahara BAZNAS Tapanuli Tengah, 4 Mei 2016.
} 
Baznas Kota Sibolga masih dengan struktur kepengurusan lama. Saat ini masih dalam proses kepengurusan sesuai PP Nomor 14. Pengurus saat ini berasal dari pegawai Kementerian Agama Kota Sibolga dibantu dengan 3 (tiga) orang staf honor. Walikota Sibolga memiliki komitmen yang kuat untuk menghimpun zakat. Melalui instruksi Walikota, seluruh SKPD diminta memotong zakat, di mana Bendahara langsung menyetorkan ke rekening Baznas Sibolga. Nishab zakat gaji pegawai ditetapkan setara dengan 85 gram emas dan dipotong 2,5\%. Di samping itu, bagi mereka yang tidak membayar zakat diinstruksikan untuk membayar infak dengan tarif sebagaimana di Kabupaten Tapanuli Tengah. Perhatian walikota yang cukup besar terhadap Baznas ditandai dengan kehadirannya pada setiap rapat kerja Baznas. Dalam rapat itu, seluruh SKPD diminta hadir mendengarkan presentasi perolehan zakat dari masing-masing SKPD. Saat ini, Baznas mengupayakan agar diperoleh dana zakat dari instansi kepolisian, kehakiman maupun BUMD, dan BUMN. Walikota Sibolga mengalokasikan dana operasional dari APBD pada tahun 2014 sebesar Rp. 50.000.000,- pada tahun 2015 Rp. 70.000.000,- dan pada tahun 2016 Rp. 50.000.000.- Honor staf sebanyak tiga orang menggunakan dana infak dan sebagian tambahan dari dana operasional. ${ }^{23}$

Struktur organisasi Baznas Kabupaten Asahan belum menyesuaikan dengan UU Nomor 23 tahun 2011 dan PP Nomor 14 tahun 20014. Saat ini Baznas sedang memproses untuk menyesuaikan struktur organisasi dimaksud. Usulan sudah diajukan Maret 2016. Bupati Asahan telah menerbitkan Peraturan Bupati (PERBUP) dalam rangka pemotongan zakat sebesar 2,5 \% dari gaji pegawai dinas seluruh dinas maupun SKPD Kabupaten Asahan. Terdapat juga pungutan infak PNS yaitu golongan I Rp. 5.000,-, Golongan II Rp. 10.000,-, Golongan III Rp. 15.000,- dan Golongan IV Rp. 20.000,-. Pengurus saat ini merangkap jabatan sebagai pegawai Kemenag Asahan dan staf honor sebanyak 2 orang. Honor bulanan masingmasing staf adalah Rp. 800.000,- dan terdapat petugas jaga malam dengan honor Rp. 700.000 perbulan. Biaya gaji pegawai berasal dari APBD sebesar Rp. 50.000.000,- pertahun. ${ }^{24}$

Kepengurusan Baznas Sumatera Utara sesuai PP 14 masih dalam proses. Untuk sementara, Gubernur telah menetapkan 5 orang pelaksana sampai terbentuk pengurus baru. Perubahan pengurus sudah diajukan sejak Desember 2015 kepada gubernur. Dukungan dana Baznas SU tidak lagi masuk APBD, tapi masuk anggaran Binsos 2015. Diharapkan tahun 2016 Baznas SU memperoleh dana operasional Rp. 1,3 milyar. Rp. 500.000.000,akan digunakan untuk belanja modal dan sisanya Rp. 800.000.000,- untuk honor pengurus dan staf, serta kegiatan. Dana operasional Baznas termasuk untuk membiaya listrik kantor dan listrik Masjid Islamic Centre. Inpres Nomor 3 belum tersosialisasi dengan baik dan sebaiknya pemotongan ke instansi di luar pemerintah dimulai di tingkat pusat dan daerah pasti akan mengikut. Honor staf tertinggi Rp. 2.000.000,- tetapi dengan perolehan dari uang makan dan uang transport akan mencapai Rp. 2.600.000,- Terdapat 9 orang staf dan 10

\footnotetext{
${ }^{23}$ Wawancara dengan Nirwan, kepala Sekretariat BAZNAS Kota Sibolga, 4 Mei 2016.

${ }^{24}$ Wawancara dengan Lelly, bidang penghimpunan Zakat BAZNAS Kabupaten Asahan, 5
} Mei 16. 
MIQOT Vol. XL No. 2 Juli-Desember 2016

orang pengurus aktif. Simba tidak berjalan dengan semestinya karena di daerah tidak memiliki perangkat dan SDM. Beberapa daerah yang tidak melaporkan penerimaannya, karena dana yang terkumpul segera tersalur di samping karena minimnya jumlah penerimaan. ${ }^{25}$

\section{Pembahasan}

Berdasarkan informasi yang digali dari masing-masing informan beberapa sampel Baznas di Sumatera Utara sebagaimana diuraikan di atas, maka beberapa isu penting dapat didiskusikan sebagai berikut :

\section{Struktur Kepengurusan Baznas Belum Sesuai UU}

Provinsi Sumatera Utara terdiri atas 25 Kabupaten dan 8 Kota. Dengan demikian, seharusnya terdapat 1 (satu) Baznas provinsi, 25 (dua puluh lima) Baznas Kabupaten dan 8 (delapan) Baznas Kota. Namun sampai dengan bulan Mei 2016 masih terdapat 4 kabupaten yang belum membentuk Baznas yaitu Labuhanbatu Utara, Gunung Sitoli, Nias Barat, dan Nias Utara. Dengan demikian, ada sebanyak 30 organisasi Baznas di Sumatera Utara. Daftar dimaksud sebagai berikut:

Tabel-1 Laporan Penerimaan Zakat Baznas Provinsi/ Kabupaten/Kota

\begin{tabular}{|c|c|c|c|c|c|}
\hline \multicolumn{6}{|c|}{ (Dalam Rupiah) } \\
\hline \multirow{2}{*}{ No } & \multirow{2}{*}{$\begin{array}{c}\text { Nama } \\
\text { Propinsi/Kab/Kota }\end{array}$} & \multicolumn{2}{|c|}{2014} & \multicolumn{2}{|c|}{2015} \\
\hline & & Zakat & Infaq & Zakat & Infaq \\
\hline & Kabupaten & & & & \\
\hline 1 & Nias & $69,158,000$ & & $27,000,000$ & $3,700,000$ \\
\hline 2 & Mandailing Natal & \multicolumn{4}{|c|}{ Belum mengirimkan laporan } \\
\hline 3 & Tapanuli Selatan & & & $263,000,000$ & $13,000,000$ \\
\hline 4 & Tapanuli Tengah & & & $3,730,524,000$ & $133,753,436$ \\
\hline 5 & Tapanuli Utara & \multicolumn{4}{|c|}{ Tidak ada penghimpunan/Penyaluran } \\
\hline 6 & Toba Samosir & \multicolumn{4}{|c|}{ Belum mengirimkan laporan } \\
\hline 7 & Labuhanbatu & $966,495,637$ & & $931,432,763$ & \\
\hline 8 & Asahan & $3,445,415,027$ & $272,438,656$ & $3,254,204,314$ & $652,375,470$ \\
\hline 9 & Simalungun & \multicolumn{4}{|c|}{ Belum mengirimkan laporan } \\
\hline 10 & Dairi & \multicolumn{4}{|c|}{ Tidak ada penghimpunan/Penyaluran } \\
\hline 11 & Karo & & & $103,568,310$ & $7,179,000$ \\
\hline 12 & Deli Serdang & $214,741,557$ & $73,520,068$ & $336,052,800$ & $79,798,500$ \\
\hline 13 & Langkat & $111,602,453$ & $1,159,847,410$ & $58,225,650$ & $1,504,938,200$ \\
\hline 14 & Nias Selatan & \multicolumn{4}{|c|}{ Belum mengirimkan laporan } \\
\hline 15 & Humbang Hasundutan & & & $21,327,548$ & $5,400,000$ \\
\hline 16 & Pakpak Bharat & & & & \\
\hline 17 & Samosir & $23,220,000$ & & $44,372,640$ & $20,415,000$ \\
\hline 18 & Serdang Bedagai & $986,771,444$ & & $52,227,10 \AA$ & $374,712,458$ \\
\hline
\end{tabular}

${ }^{25}$ Wawancara dengan Sahrul Jalal, Bendahara BAZNAS SU, 7 Mei 2016. 
Saparuddin Siregar: Problematika Fundraising Zakat

\begin{tabular}{|c|c|c|c|c|c|}
\hline 19 & Batu Bara & $312,002,043$ & $238,150,964$ & $320,398,579$ & $122,073,485$ \\
\hline 20 & Padang Lawas Utara & \multicolumn{4}{|c|}{ Tidak ada penghimpunan/Penyaluran } \\
\hline 21 & Padang Lawas & \multicolumn{4}{|c|}{ Belum mengirimkan laporan } \\
\hline 22 & Labuhanbatu Selatan & $206,601,231$ & & $931,432,763$ & \\
\hline 23 & Labuhanbatu Utara & \multicolumn{4}{|c|}{ Belum Terbentuk } \\
\hline 24 & Nias Utara & \multicolumn{4}{|c|}{ Belum Terbentuk } \\
\hline 25 & Nias Barat & \multicolumn{4}{|c|}{ Belum Terbentuk } \\
\hline & Kota & & & & \\
\hline 1 & Sibolga & $947,243,899$ & $83,665,724$ & $1,127,612,437$ & $153,607,250$ \\
\hline 2 & Tanjungbalai & $85,695,253$ & $45,777,192$ & $118,400,000$ & $16,200,000$ \\
\hline 3 & Pematangsiantar & $188,564,000$ & $52,595,500$ & $191,471,900$ & $2,656,000$ \\
\hline 4 & Tebing Tinggi & $658,791,609$ & & & \\
\hline 5 & Med a n & $61,250,520$ & & & \\
\hline 6 & Binja i & $82,502,240$ & $22,210,030$ & $508,124,770$ & $33,274,938$ \\
\hline 7 & Padangsidimpuan & & & $324,223,000$ & $252,019,480$ \\
\hline \multirow[t]{2}{*}{8} & Gunungsitoli & \multicolumn{4}{|c|}{ Belum Terbentuk } \\
\hline & Propinsi & & & & \\
\hline \multirow[t]{3}{*}{1} & BAZNAS Propinsi SU & $1,705,066,702$ & $1,709,484,491$ & $2,211,456,217$ & $1,453,137,053$ \\
\hline & Total Penghimpunan & $10,065,121,611$ & $3,657,690,035$ & $14,555,054,796$ & $4,828,240,270$ \\
\hline & Sumber BAZNAS SU & & & & \\
\hline
\end{tabular}

Struktur organisasi Baznas provinsi maupun Baznas Kabupaten/Kota hingga bulan Mei 2016 belum menyesuaikan kepada PP Nomor 14 tahun 2014 tentang Pelaksanaan UU Nomor 23 tahun 2011 tentang Pengelolaan zakat. Satu-satuanya Baznas yang telah menyesuaikan dengan PP dimaksud adalah Baznas Kabupaten Langkat, yaitu pada bulan Maret 2016. Dua puluh sembilan Baznas termasuk Baznas provinsi masih dalam proses pengajuan kepada kepala daerahnya masing-masing.

Dengan sturuktur organisasi Baznas se-Sumatera Utara yang telah berakhir dan belum dilakukan pengangkatan kembali telah mengakibatkan terjadinya kevakuman organisasi. Kevakuman organisasi menyebabkan kegiatan fundraising maupun penyaluran tidak dilaksanakan dengan sepenuh hati oleh pengurus. Dengan demikian, organisasi Baznas provinsi dan kabupaten/kota tidak dapat diharapkan akan dapat bekerja dengan optimal.

Untuk mendorong percepatan penyesuaian struktur pengurus ini, diharapkan Baznas se-Sumatera Utara bersama Baznas Indonesia menyatukan kekuatan mendesak kepala daerah masing-masing untuk segera membentuk kepengurusan. Sesuai UU Nomor 23 tahun 2001, dalam hal gubernur atau bupati/walikota tidak mengusulkan pembentukan Baznas provinsi atau Baznas kabupaten/kota, menteri atau pejabat yang ditunjuk dapat membentuk Baznas provinsi atau Baznas kabupaten/kota setelah mendapat pertimbangan Baznas. Tentang keinginan Baznas pusat agar Baznas Provinsi serta Baznas kabupaten/ kota segera menyesuaikan kepada sturuktur yang baru menurut UU. Sesuai keterangan Syahrul Jalal (Bendahara Baznas provinsi Sumatera Utara), Baznas pusat menargetkan pada akhir Oktober 2016 seluruh organisasi Baznas di Sumatera Utara telah menyesuaikan kepada PP Nomor 14 Tahun 2014. 


\section{Kurangnya Dukungan APBD/APBN Pemkab/Pemko}

Sesuai UU Pengelolaan zakat, Pemerintah memberi dukungan APBD untuk dana operasional Baznas di wilayahnya masing-masing. Baznas provinsi Sumatera Utara diharapkan mendapat dukungan dana Rp. 1,3 Milyar. Sebesar Rp. 800.000.000,- dari dana ini akan digunakan untuk honor pengurus, staf dan berbagai kegiatan. Sedangkan Rp. 500.000.000,adalah dana operasional kantor. Baznas provinsi telah mendapat dukungan yang relatif memadai untuk dapat beroperasi secara normal. Namun masih lebih banyak Baznas yang tidak memperoleh dukungan dana dari pemerintah kabupaten/kota, sehingga tidak dapat membayar honor yang pantas untuk staf maupun melakukan kegiatan pengerahan dana zakat yang lebih gencar.

Pada umumnya Baznas tidak mengambil hak amil untuk menjadi dana operasionalnya, tetapi mengharapkan kepada pemerintah daerah/kota. Baznas Asahan mendapat dukungan APBD Rp. 50.000.000,- pertahun. Baznas Deli Serdang hanya memperoleh dana operasional kegiatan Rp. 25.000.000,- pertahun. Baznas Binjai tidak mendapat bantuan dana. Baznas Sibolga mendapat bantuan dana operasional Rp. 50.000.000,- dan Baznas kabupaten Tapanuli Tengah mendapat dana hibah Rp. 50.000.000,- pertahun. Rendahnya dana operasional ini menunjukkan betapa UU Nomor 23 tahun 2011 tentang pengelolaan zakat yang menyebutkan Baznas dibiayai oleh dana APBD maupun APBN tidak dapat terlaksana dengan efektif.

\section{Profesionalisme Pengurus / Staf}

Belum terbentuknya organisasi Baznas yang profesional sebagaimana yang dikehendaki PP Nomor 14 tahun 2014 dan minimnya dukungan dana APBD/APBN berimplikasi terhadap profesionalisme pengurus dan staf. Secara umum, pengurus Baznas berasal dari pejabat Kementerian Agama. Dari tujuh Baznas yang menjadi subjek penelitian ini, satu diantaranya (Baznas Kabupaten Tapanuli Tengah) kepengurusannya berasal dari pemerintah kabupaten. Untuk pengurus Baznas provinsi, Ketua dan Bendaharanya tidak terikat sebagai pegawai negeri, namun pengurus lainnya adalah para dosen yang memiliki aktivitas mengajar yang padat. Pengurus Baznas kabupaten/kota tidak memperoleh honor khusus sebagai pengelola. Para pengurus dapat memperoleh honor berupa dana kegiatan terkait dengan pengelolaan zakat yang memperoleh anggaran dari dana APBD.

Adapun staf yang bertugas di Baznas, terdapat di antaranya staf yang berasal dari Kementerian Agama ditempatkan di Baznas. Baznas memiliki staf honor yang pembayaran honornya masih belum mencapai ketentuan upah minimum. Terdapat seorang staf di Baznas Tapanuli Tengah hanya menerima honor Rp. 500.000,- perbulan. Ada yang memperoleh honor Rp. 700.000,- sampai Rp. 800.000,- perbulan di Baznas Asahan dan Rp. 1.200.000,yang bertugas di Baznas Langkat. Untuk staf di Baznas provinsi telah memperoleh honor Rp. 2.000.000,- perbulan. 
Pengurus Baznas yang masih rangkap di instansi pemerintah dan belum mengacu kepada PP Nomor 14 tahun 2014, akhirnya menyebabkan pengelolaan yang tidak fokus terhadap Baznas masing-masing. Demikian pula staf yang tidak mendapat honor dengan semestinya, maka tidak dapat diharapkan berkontribusi secara optimal kepada Baznas.

\section{Kinerja yang Rendah dalam Penghimpunan Zakat}

Rendahnya penghimpunan zakat adalah karena belum seluruh daerah mewajibkan membayar zakat dari gaji PNS, BUMN, BUMD demikian pula dari instansi Kepolisian, Kehakiman dan Swasta. Pada saat ini, dengan adanya Inpres Nomor 3 tahun 2014 tentang Optimalisasi Pengumpulan zakat, seyogianya para pimpinan instansi sudah mengeksekusi pelaksanaan Inpres itu. Namun inilah yang disayangkan bahwa sebagian di antaranya tidak segera mengambil kesempatan untuk melakukan peran bagi kepentingan agama selagi di tangannya ada kewenangan untuk melakukan yang terbaik bagi agamanya.

Apabila seluruh instansi dapat melaksanakan pemotongan zakat langsung dari penghasilan pegawai, maka sumber daya manusia di Baznas tidak lagi diperlukan untuk kegiatan penghimpunan dana yang bersumber dari PNS, tetapi dapat melakukan penguatan penghimpun dari swasta dan masyarakat. Selain itu Baznas akan lebih memperkuat perannya dalam rangka menyalurkan zakat untuk produktif bagi mustahiq-nya. Jumlah penghimpunan masing-masing Baznas pada tabel-1.

\section{Transparansi}

Aspek transparansi adalah keterbukaan menyampaikan laporan kepada publik, misalnya dalam bentuk informasi website. Saat ini Baznas provinsi telah memiliki website yang dapat diakses masyarakat dengan alamat www.sumut.baznas.go.id. Namun website ini belum menyajikan laporan tahunan atau laporan bulanan. Menurut keterangan staf Baznas Sumatera Utara, pada address web sebelumnya telah disajikan laporan keuangan tahunan maupun bulanan, namun dengan perpindahan alamat web, proses upload data belum selesai dilakukan.

Menyangkut data penghimpunan dan penyaluran zakat, masih disayangkan bahwa meskipun UU Pengelolaan zakat sudah diberlakukan sejak 2011, di mana Baznas Indonesia Pusat memiliki wewenang koordinator dan menerima laporan dari seluruh Baznas dan Laz, namun hingga Mei, Baznas belum mampu menyediakan data yang bersifat konsolidasi nasional seluruh mmil zakat. Kurangnya kemampuan menyampaikan transparansi pengelolaan zakat ini dapat berpengaruh kepada kepercayaan dan keinginan masyarakat untuk menyerahkan zakatnya kepada Baznas/Laz.

Selain Baznas provinsi, belum ada Baznas kabupaten/kota yang memiliki website. Untuk efisiensi dalam transparansi ini, sebaiknya masing-masing Baznas kabupaten/kota 
dapat memanfaatkan website Baznas provinsi untuk penyajian laporan secara bulanan maupun berbagai kegiatannya.

Menyangkut berbagai laporan, Baznas Indonesia telah menyiapkan software untuk penyusunan laporan keuangan yang dinamakan SIMBA (Sistem Informasi Manajemen Baznas). Namun, software ini belum digunakan oleh masing-masing Baznas se-Sumatera utara dengan baik, karena ketidaksiapan perangkat dan sumber daya manusia. Untuk hal ini, Baznas provinsi perlu berinisiatif mengumpulkan kembali untuk pelaksanaan training. Apabila data-data telah di-entry ke dalam software SIMBA, maka diharapkan laporan dapat diintegrasikan secara wilayah Sumatera Utara maupun nasional.

\section{Kesimpulan dan Saran}

Pengelolaan zakat di Indonesia telah memiliki payung hukum yang jelas berdasarkan UU Nomor 23 tahun 2011 tentang Pengelolaan zakat dan dilengkapi dengan Peraturan Pemerintah Nomor 14 tahun 2014 tentang Peraturan Pelaksanaan UU Nomor 23 tahun 2014 tentang Pengelolaan zakat. UU dan PP ini didukung pula dengan Instruksi Presiden Republik Indonesia Nomor 3 Tahun 2014 tentang optimalisasi pengumpulan zakat. Akan tetapi keberadaan UU ini belum terlaksana efektif dalam penerapannya.

Permasalahan yang dialami Baznas se-Sumatera Utara menyangkut efektivitas UU ini adalah sebagai berikut. Pertama, usaha Baznas yang masih kurang untuk mendesak pemerintah daerah untuk mewujudkan struktur organisasi sesuai PP No 14 tahun 2014. Di samping pula kurangnya perhatian pemerintah dalam merespons permasalahan yang terkait dengan Baznas. Kedua, kurangnya perhatian pemerintah terhadap pengembangan zakat yang berimplikasi pada tertundanya pelaksanaan Instruksi Presiden Nomor 3 tahun 2014 dalam rangka optimalisasi zakat, dan rendahnya dukungan anggaran dari pemerintah kabupaten/kota terhadap operasional masing-masing Baznas. Ketiga, Baznas se-Sumatera Utara tidak memiliki sumber daya manusia yang profesional. Ini disebabkan belum dilakukannya penyesuaian pengurus sesuai PP Nomor 14 tahun 2014 dan juga tidak memadainya anggaran yang tersedia dari pemerintah daerah/kota. Sumber daya manusia yang ada kurang profesional, karena pada umumnya jabatan pengurus dijabat rangkap dengan tugas-tugas di pemerintahan. Rekrutmen staf yang berkualitas tidak mungkin dilakukan, karena tidak dapat diberikan gaji yang layak. Kelemahan profesionalisme SDM ini berimpikasi pada rendahnya perolehan penghimpunan zakat, yang tentunya disebabkan usaha yang kurang kuat melakukan fundraising. Keempat, sistem administrasi dan sistem keuangan Baznas masih lemah, sehingga tidak dapat melakukan transparansi keuangan maupun kegiatan melalui publikasi internet. Lemahnya administrasi tercermin dari proses kerja yang masih manual. Terdapat Simba (Sistem informasi Baznas), namun belum dapat diintegrasikan untuk menghasilkan laporan dengan baik, karena ketidaksiapan operator dan akses internet. 
Penelitian ini merekomendasikan untuk segera dilakukan pengangkatan pengurus Baznas masing-masing pada tingkat provinsi maupun kabupaten/kota sesuai dengan UU Nomor 23 tahun 2011 tentang pengelolaan zakat dan Peraturan Pemerintah Nomor 14 tahun 2014, dan peraturan Baznas Nomor 1 tahun 2014. Dengan pengangkatan ini, diharapkan pengurus dapat bekerja lebih profesional dalam menghimpun dan menyalurkan zakat. Penelitian ini merekomendasikan segera direalisasikan pelaksanaan Instruksi Presiden Republik Indonesia Nomor 3 tahun 2014 tentang optimalisasi pengumpulan zakat, di mana diharapkan terdapat Perda pemotongan zakat dan instruksi gubernur bupati/ walikota untuk pemotongan zakat dari gaji masing-masing Pegawai Negeri maupun pegawai BUMN. Dalam upaya penyediaan dan penyiapan pembiayaan Baznas, Baznas perlu berkoordinasi dengan pemerintah dan DPRD agar disiapkan anggaran yang memadai untuk operasional Baznas di dalam APBD.

\section{Pustaka Acuan}

Alam, Syariful. "Baznas Targetkan Perolehan Zakat 2015 Rp. 4,22 Triliun," dalam http:// www.rri.co.id.

Anto. "Diperkirakan Zakat di Sumut Rp. 2 Triliun," dalam http://harian.analisadaily.com, 20 Februari 2016. 3 Mei 2016.

Beik, Irfan Syauqi. “Outlook Zakat Nasional 2014, Tantangan UU No 23/2011," dalam http://www.republika.co.id.

Md. Salleh, Arifin, dan Ramawan Abdul Rahman. "The Important Role of Zakat Organizations to Reinforce World Zakat Program," dalam Zakat for Poverty Alleviation. Jakarta: FOZ dan WZF, 2011.

Nasar, M. Fuad. "Zakat dalam Riwayat Pemerintahan Indonesia," dalam http://pusat. baznas.go.id.

Nordin, Rawi, dan Abdullah Said. "Perundangan Zakat di Malaysia," dalam Fiqh Zakat Malaysia. Kuala Lumpur: Pusat Penerbitan Universiti Teknologi MARA, 2011.

Qardhâwî, Yusuf. Fiqh Zakâh, Juz II. Beirut: Muassasâh Risâlah, 1988.

Ra'ana, Irfan Mahmud. Sistem Ekonomi Pemerintahan Umar Ibn al-Khatab. Jakarta: Pustaka Firdaus, 1997.

Redaksi Forum Zakat. "Ini Bukti Potensi Zakat di Inonesia Besar," dalam http://forumzakat.org.

Sari, Mutiara Dwi, et al. "Review on Indonesian Zakah Management and Obstacles," dalam Social Sciences, Vol. 2, Nomor 2, 2013.

Yulianti, Rahmani Timorita, dan Ratnawati Yuni Suryandari. "Suatu Ulasan Kritis tentang Peranan Kepimpinan dalam Membangun Profesionalisme Institusi Zakat," dalam Geografia: Malaysian Journal of Society and Space, 10 Issue 2, 2014.

"IB Peduli," dalam http://pusat.baznas.go.id/ib-peduli.

"Prospek Zakat Indonesia 2016," dalam http://www.dompetdhuafa.org. 
MIQOT Vol. XL No. 2 Juli-Desember 2016

Qanun Aceh No. 10 tahun 2007 tentang Baitul Mal.

Undang-undang RI Nomor 23 Tahun 2011 Tentang Pengelolaan Zakat.

Peraturan Pemerintah Republik Indonesia Nomor 14 tahun 2014 tentang Pelaksanaan UU Nomor 23 Tahun 2011 tentang Pengelolaan Zakat.

Inpres RI Nomor 3 Tahun 2014 tentang Optimalisasi Pengumpulan Zakat di Kementerian/ Lembaga, Sekretariat Jenderal Lembaga Negara, Sekretariat Jenderal Komisi Negara, Pemerintah Daerah, Badan Usaha Milik Negara, dan Badan Usaha Milik Daerah Melalui Badan Amil Zakat Nasional. 